\title{
Megachurches and Popular Culture: On Enclaving and Encroaching
}

\author{
Simon Coleman and Saliha Chattoo
}

Christians have always built large churches. Imposing cathedrals dominated the architectural profiles and often the economies of cities in medieval Europe, and spread into the New World along with colonisation and missionisation (Coleman and Bowman 2018). Yet, while such churches are often huge, we do not think of them as mega. Their size - expressive of ecclesiastical authority - has a different quality to the dynamic, ostensibly more democratic forms of expansion that we associate with today's megachurches. ${ }^{1}$ If many Gothic and neo-Gothic cathedrals expanded upwards towards the heavens while ostentatiously occupying urban centres, contemporary megachurches have tended to expand sideways, taking up large swathes of land in suburban areas, or repurposing large-scale facilities such as sports arenas. Furthermore, these differences in models of growth go beyond the spatial or the architectural. Cathedrals have tended to represent 'high culture', embodying national identity, craftsmanship, education, and patronage. Megachurches inhabit a very different cultural realm, relying on an ability to attract people to their services and consumers to their products. An empty cathedral (and there are many) still provides an important symbolic and civic function. An empty megachurch serves no purpose at all.

This chapter demonstrates the importance of popular culture to the development of megachurches, showing its intimate connection with such churches' performances of what is often made to seem like ineluctable expansion. Our use of the word performance here is very deliberate, since it is meant to convey the sense of both producing growth and displaying it through a variety of media (see also Goh 2008; Maddox 2012). We intend to show that the popular culture engendered by megachurches is typically marked by a creative if

1 Thus Goh (2008) argues that the Australian Hillsong Church explicitly prides itself on the fact that its church complex contrasts with the architecture of traditional cathedrals, displaying more modern forms of functionality and openness. 
sometimes tension-filled negotiation between two models or ethical approaches to performing the mega: what we call 'enclaving' and 'encroaching'. Enclaving is oriented towards fellow believers, encouraging them to perceive how apparently separated areas of their life can come under church influence, ranging from worship to leisure to family and even work. It draws a moral boundary around different practices while re-establishing articulations among them, so that for instance prayerful and pleasurable activities come to be juxtaposed ethically, socially, and spatially. While the idea of an enclave tends to imply a restricted community, in evangelical eyes it is always in a potential state of expansion. This type of moral encompassment can respond to the anonymising challenges and temptations of the post-modern city, much as nineteenth-century evangelists had to take account of burgeoning urban life in developing their styles of preaching, worship, and church life. Encroachment, on the other hand, involves a more explicit attempt to move into and aggressively (re-)moralise secular realms, seeking fresh markets alongside new converts as believers carry out their evangelical duty of reaching out to nonbelievers, not merely through testimony but also through product placement of such goods as music, films, theatrical performances, or even clothes.

Like many analytical binaries, these models are meant to be productive to think with rather than defended as rigid categories. Engaging simultaneously with both ethical frames of action informs the lives of many of those who engage with megachurches. While enclaving and encroaching have long constituted broadly evangelical ways of viewing and responding to the world, they take on particular characteristics in the contemporary landscape of megachurch activity. As we note in the next section, we should be cautious in arguing for the exceptionality of the present-day, but many megachurches do seem notable not only for their attitude towards size but also for the extent to which they challenge behavioural, material, and aesthetic boundaries previously assumed to exist between Christian and secular forms of activity. Whether enclaving or encroaching, the actions of megachurch members therefore complicate conventional distinctions between exclusivist Christian piety and the behaviours or even desires of non-believers, with sometimes unpredictable results.

Let us provide a brief initial example of what we mean. In the 1980s, one of us (Coleman) began to carry out fieldwork in the neo-Pentecostal, Prosperity Gospel-oriented Word of Life Foundation situated just outside Uppsala in Sweden. During that decade, the Foundation was in its first stage of growth, moving swiftly from being a relatively modest congregation into becoming a fullyfledged megachurch, with over two thousand members, a Bible School and university, a publication business, and so on. Although still relatively small 
compared to other Swedish religious movements, the Word of Life caused a national panic at the time, accused by secular observers and many fellow Christians of being both fanatically religious ('fundamentalist') and not sufficiently religious enough ('money-grabbing'). Many factors lay behind such controversy (Coleman 200o), but for our purposes the most notable are those that involved the group's deep involvement in popular cultural forms. The Word of Life differed from more traditional Swedish Pentecostal congregations of the time in its staging of theatrical performances, encouragement of some rock music, aggressive marketing of consumer goods ranging from evangelical videos to coffee cups, and celebration of such 'secular' lifestyle accessories as fine clothes and expensive cars. It appeared to outsiders to represent an anomalous hybrid of deep commercialisation alongside a highly conservative emphasis on adherence to biblical literalism. Yet, with hindsight, we might see the Word of Life as being in the vanguard - at least in Sweden - of an attitude towards popular culture that has, if anything, become increasingly evident among megachurches, especially those promoting greater or lesser degrees of the Prosperity Gospel: a sense that active Christians should preserve their own morality (enclaving) even as they also have a moral obligation to work through popular, material forms, such as money, popular music, film, sport, and so on appropriating ('encroaching' upon) them for Christian purposes.

In considering such attitudes towards culture, brief comparisons and contrasts with cathedrals are again helpful. The latter offer impressive liturgy, precious material objects, and so on, combining high culture and high cultural capital with a 'low threshold' of entry adapted to the need to make cathedral spaces as accessible to as many people as possible: ${ }^{2}$ generally speaking, at least during visiting hours, anybody is allowed in to view a cathedral, albeit sometimes for a fee. Megachurches cannot usually offer much in the way of historical artefacts, but operate through establishing their own low thresholds of accessibility to their goods and services: after all, little is to be gained by scaring off potential converts or customers. Thus Charles Brown notes that the 1960 in particular saw the emergence of a "large scale, mass-produced, and consumed evangelical material culture", ${ }^{3}$ and one that forced producers to work out how to promote their faith simultaneously "toward both fellow Christians and those outside the subculture" (2012: 115). While Brown also traces an overall shift in emphasis, in the United States at least, from a focus on non-Christians (1950s-1970s) towards a more contemporary stress on Christians themselves, it remains necessary for megachurch members to strike a fine balance between

2 For a discussion of the use of this term see Coleman and Bowman (2018).

3 See also McDannell (1995). 
reinforcing their subculture and expanding that subculture (and market) so that it does not become stagnant or lose conversionary ambition.

If achieving such a balance is a challenge, it is one that fires what Christine Gardner (2017: 162) refers to as the "evangelical imagination", and its constant wrestling with the "push-pull effects" of being "in the world but not of it". In the process, the use of popular culture enables forms of public witness through relatively unthreatening media: "If fewer lost souls are coming to church, then the Good News needs to come to them through a Christian pop song or movie" (2017: 164). Thus John Connell (2005: 316-317) calls megachurches both "fullservice" (providing more than just obviously religious needs) and "seeker sensitive" (tailoring programmes to cater to the needs of people who have no fixed church).

As Gardner notes (2017: 168), the blurring of genres that results from such activity goes against stereotypes of evangelicals being always engaged in an inherently antagonistic relationship with secular culture, and indicates how such Christians may simultaneously criticise but also borrow the cultural forms of non-religious neighbours. We should not make the mistake of seeing this borrowing as a mere surrender to self-indulgence or an indication of the triumph of secular values. To begin with, it is important to understand the necessity - at least in ideal terms - for believers to steel themselves to engage in practices of encroachment as well as enclaving: in other words, it takes a certain discipline to be constantly oriented toward the possibility of converting potentially unwilling others to the faith. More broadly, however, the appropriation of secular forms provides a variant on a deeper theme of conversion that can be traced within broadly evangelical, and certainly Pentecostal and charismatic congregations. Joel Robbins (2004) has traced the variety of ways in which such Christians engage with other cultures, ranging from demonisation of the non-Christian Other to a strategic adoption of the latter's local idioms and cultural forms, even while investing such forms with new moral values. For Robbins, this combination of cultural preservation and appropriation is one of the reasons why Pentecostalism in particular has managed to become such a successful global movement, even as it encounters a multitude of local cultures. We do not need to adapt Robbins's argument too much to make the case for a megachurch encroachment into, and yet re-evaluation of, secular cultural forms. For such Christians, examples of 'low' cultural media such as rock music or wrestling (Ebel 2009) should not be dismissed as mere secular entertainment when they might prove effective bridges of communication with non-Christians.

In the following, as we trace megachurch engagement with popular culture, we begin with a short historical section, examining the current megachurch 
phenomenon in the light of its immediate forebears. We then explore our central themes of enclaving and encroachment in more detail, while drawing on examples taken from within and beyond the Euro-American world. ${ }^{4}$ As we shall see, a comparative perspective on the forms of popular culture promulgated by megachurches demonstrates similarities but also some significant differences in understandings of culture, popularity, and the meaning of the 'mega'.

When the Word of Life's impressive new building was constructed in an industrial suburb of Uppsala in the 1980 s it was widely mocked by its critics, who called it a 'sports hall' (Coleman 200o), barely distinguishable from the warehouses and sales rooms surrounding it. The somewhat brutalist architectural style of the foundation's headquarters provided a particularly marked contrast to the city's other outsize religious building, its famous Gothic cathedral, begun in the thirteenth century and situated down the hill from the megachurch. Yet, if the Word of Life could not compete with the cathedral's medieval credentials, it nonetheless drew on another historical genealogy, and one where the imagery of the sports hall was not so far out of place. As Robert Brenneman and Brian Miller (2016: 85) write of the corporate, shopping-mall style of Willow Creek megachurch located in a suburb of Chicago, such buildings recall the nineteenth-century revivalist liking for large, functional urban buildings that minimised religious symbols and maximised sight lines and clarity of acoustics. ${ }^{5}$ David Eagle (2015: 589) takes the historical resonances back still further, to the sixteenth-century Huguenot architect Jacques Perret, who developed "an early Protestant vision for a large, multi-functional worship space".

As Brenneman and Miller note (2016), such architectural infrastructures aid the functioning of buildings as instruments of evangelism - or, we might say, any mass event. It is no surprise that some megachurches, including that of Joel Osteen's famous Lakewood congregation in Houston, are adaptations of former sporting arenas (Carney 2012), just as the renowned nineteenth-century evangelist Charles Finney agreed (albeit sometimes with some misgivings,

4 Connell $(2005: 316)$ compares the dimensions of American megachurches, containing more than 2,000 worshippers each Sunday, with Korean 'gigachurches', which attract some 10, 000 members to Sunday worship.

5 Eagle (2015: 595) notes that the English non-conformist, Charles Haddon Spurgeon, constructed the largest Protestant church building of his day - the Metropolitan Tabernacle, with room for 6,000 listeners. 
according to Kilde 1999: 176) to take over secular theatres in order to preach his message to urban America. Such venues were not only practical for a preacher, but they also literally reached out into secular space, and Finney's 'New Measures' methodology was explicitly designed to lower the institutional threshold for conversion and acceptance into the faith, granting instant church membership to those declared to be saved (Carney 2012: 62-63).

Aside from the use of secular-looking venues, the provision of popular forms of entertainment has long historical roots in revivalism. Brown (2012: 113) describes how, in the eighteenth century, Charles Wesley borrowed from popular opera, English folk melodies, and even popular drinking songs to write his hymns, and in the next century, the American evangelist Dwight Moody ill-educated but in tune with the times - would deploy music as a means of attracting crowds (Brown 2012: 115). One of the most famous American evangelists of the twentieth century, Aimee Semple McPherson, built up a media empire designed to project her voice and image over the radio and into movie theatres, and she moved to Los Angeles in 1918, constructing a temple that looked similar to surrounding places of entertainment (Carney 2012: 63). As Carney puts it, McPherson constructed a form of Hollywood religion, where a radio station and Bible College might easily be juxtaposed, and where she understood the advantages of appearing in adverts before secular feature films, asking moviegoers to convert even as they were waiting to be entertained (2012: 64). A later generation of preachers, the televangelists, would harness the power of Christian-themed variety television shows, involving both music and celebrities, to garner attention. Some buildings - such as Robert Schuller's 'Crystal Cathedral', an extraordinary part of the southern Californian architectural landscape - would be built precisely to accommodate television cameras (Beckering 2011: 41-42).

We have provided the briefest of sketches of certain antecedents to contemporary megachurch activity and expansion - an expansion that has now come to inhabit the virtual landscape of social media alongside earlier forms of communication. We hope to have demonstrated the resonances and affinities between burgeoning urban populations, strategic forms of evangelism, and the broadening cultural power of Christians who, especially in the period following the Second World War in the United States and to some degree elsewhere, have gained more and more access to material resources of communication. In response to the challenge of bringing Christians into the fold, Christian leaders ranging from Charles Finney to leaders of the Church Growth movement of the 1980 s have understood the need to adopt systematic and entrepreneurial approaches (Eagle 2015: 591) in their mission, combining popular appeal with careful planning and an eye for the market. As many evangelicals have 
increasingly moved away from stricter, Calvinist understandings of Christian discipline and piety, the use of popular culture as means of entertainment, source of income, but also bridge into secular realms of action has become more evident than ever before. Even among the already converted, popular culture provides potent media to retain the interest of younger generations of Christians who combine access to consumer choices with relatively less respect for hierarchy than in earlier periods (compare Connell 2005: 318). At the same time, the very act of marketing appeals to the entrepreneurial character of much post-War evangelicalism, and one that has displayed increasing confidence with the prospect of operating in the public spheres of many societies within and beyond the Euro-American world (Oosterbaan 2015). And yet such culture still contains its dangers, its possibilities for indulgence and temptations of the flesh. In the next section, we explore some of the ways in which popular culture is deployed but also corralled for megachurch purposes through strategies that we call enclaving.

\section{Expansive Enclaves}

Drawing on the work of Mary Douglas (1993), the anthropologist Jackie Feldman (2002: 91) talks of the importance of the enclave in creating a boundary in relation to the wider world but also permitting relative freedom of expression within. In these terms the enclave is a social formation that needs to use carrot rather than stick in order to retain its members, given than it is relatively easy to move elsewhere. For Douglas and Feldman, the enclave tends to emphasise the voluntary character of its membership along with the value of each individual participant, but also the need to protect the self from threatening external forces.

Feldman's argument is based on ethnography of young Israelis making trips to sites of the holocaust in Poland, but in certain respects his and Douglas's depiction of the enclave fits megachurches quite well. Admittedly, such churches may be run by an authoritative head pastor, and yet in practice they depend on the willingness of people to turn up to fill auditoria, purchase goods, and provide, through their very presence, an impression that the 'mega' is being created and that a successful enterprise is underway. One way of retaining the participation of people who have other options is to expand horizontally - not only spatially but also socially and culturally. Carney (2012: 68 ) stresses the ability of many megachurches to become "consciously selfsustaining communities", and in order to do so they may include not only worship facilities but also "game rooms, bowling allies, kitchens and cafes, movie 
theaters - anything a contemporary American worshipper would want for entertainment". The provision of such facilities in the context of suburban life carries with it a number of advantages: it is convenient for busy families, it encourages socialisation among congregation members, and it suggests that religion can be fun as well as challenging. Importantly, it provides a measure of security, especially in contexts where gated communities may be favoured by richer residents and thus form part of the imagery of successful middle-class life. Parents of teenagers also gain a degree of surveillance over the activities of their offspring.

Thus exclusivity but not complete exclusion of outsiders is promoted, and if such measures seem attractive in the context of a north American suburb, they may take on even more powerful resonances in other parts of the world. In the summer of 2018 Coleman carried out fieldwork in Mountain of Fire and Miracle Ministries (MFM), a Nigerian Pentecostal denomination founded in 1989, with its headquarters based in a former slum area adjoining the University of Lagos campus. Not just the main worship hall, but the entire area speaks volumes about the aspirant culture of the group. So-called 'area boys' (aggressive gangs of street children, common in Lagos) have been chased away or reformed, incorporated as members of the Church, and traffic is regulated to create a streetscape that contrasts in its relative peace and order to the urban cacophony beyond - aided by a gate that marks the perimeter of M FM influence. Some buildings bought up by the ministry are even painted purple, the colour of its 'brand'. Yet, this area is not merely a zone of overt regulation. Among the services on offer are a café, a music school (where training in popular and classical music is offered), and a large shop stocked not only with recordings of services and Christian books, but also the sports kit of MFM FC, a successful professional football team owned by the denomination. What is being displayed and performed - is not only the ability of the church to expand into and reform parts of the 'unruly' city, but also lessons in a new lifestyle of rational consumption, self-development, and morally approved entertainment.

The MFM gated zone and other similar megachurch activity also express a further form of enclaving, operating at an economic level. Provision of leisure services and goods both furthers the activities of the church and helps provide it with resources to continue its activities. As Brown argues (2012: 114), despite its size the industry of evangelical popular culture is often relatively unnoticed by many outsiders, even as it contains a significant blend of ministry and commerce. Indeed, megachurch denominations around the world tend to create franchises that involve the movement of consumer items across national and transnational contexts (Coleman 2017). Such movement provides an excellent example of what we are calling 'expansive enclaving' - the sense of covering 
the whole globe with an evangelical brand, while finding primary markets in fellow believers whose consumption practices reflect the religious identities they wish to create and project. At times, of course, such identities may blend religious and ethnic identities, and Jonathan Walton (2011: 144; see also Johnson 2011) traces the distinct history of African American megachurches in American Protestantism, while noting the ways in which such churches reflect a larger African American outward push from the centres of cities during the latter part of the twentieth century.

One of the first scholars to point out the significance of seemingly trivial material culture to evangelical (and other) Christians was the art historian Colleen McDannell (1995; see also Brown 2012: 115) who pointed out that objects such as bumper stickers, jewellery and T-shirts were not only of economic importance, but also provided visible and tactile means through which to enact a religious subculture. In this way the deployment of everyday and yet branded material culture helps form a certain kind of community, albeit one that competes in the public sphere with numerous other groups that also mark out their identity through clothes, mugs, stickers, and so on. We might therefore think of the MFM shop mentioned above as a place of commerce but also much more than that - a context in which members can come together outside of church services and engage in acts of self-formation that are, in their way, quite as effective as forms of prayer or Bible reading. It seems fitting that when Coleman bought MFM football shirts for his children, the manager of the shop accompanied such purchases with the gift of a free book containing the writings of an MFM preacher.

Reflecting on the relative success of evangelical products, John Lindenbaum (2012: 69) states that "popular music featuring evangelical Christian lyrics, is one of the most widely consumed forms of commercial entertainment for America's 70-80 million white evangelical Christians". He provides a highly nuanced analysis of the way in which it is appreciated and deployed by believers as it helps to 'spiritualize' their everyday lives. His focus is on an evangelical megachurch in the suburbs of Sacramento, California, and its activities during what are called First Friday concerts - monthly occasions dedicated less to outsiders and more to the work of retaining members, including many youngsters brought up in the faith. Such occasions provide opportunities for organisers to propagate culturally appropriate music to youth, attempting to persuade "Christian teens and pre-teens that they can be themselves - interested in loud music and violent movies, insecure, flawed - and still be Christians" (2012: 79). The production and consumption of this type of music parallel but are also partially removed from a purely secular, market sphere. Lindenbaum recounts that in interviews fans, musicians, and organisers portrayed commercial success as admirable, but only along certain delimited ethical 
lines, even as he observed the youth pastor instructing the audience to "buy some merch" after concerts. Thus a musician noted (2012: 74):

I make money playing shows and I don't think there is anything wrong with that .... The only reason I have issue with that is when you are making Christian music strictly for profit and not at all for Christ.... It shouldn't be strictly about the money.

According to Lindenbaum, concerts encourage people's self-identification with Christian industry products that do not differ stylistically from other genres of popular music, but which are nonetheless classified as set apart through their value-added Christian dimension. For the analyst, part of the fascination of such practice is precisely the carefully calibrated balance it must strike, retaining proximity to and yet ethical distance from unredeemed forms of popular culture.

In these discussions of megachurch branding and in particular the influential role of music in creating a sense of expansion, the type example must be Hillsong, an Australian-founded network of megachurches oriented toward youth-focused services and the professional production and marketing of poprock (Abraham 2018: 2). The story of Hillsong is one of growth and diffusion across and through a variety of media, after its foundation in suburban Sydney in 1982. Goh (2008) makes the intriguing claim that the church tries to locate itself not only within evangelical practices, but also in the orbit of other populist 'megastructures' such as malls, tourist attractions and even the iconography of global cities such as Sydney. Connell (2005: 328) describes megachurches such as Hillsong as new "cathedrals of suburbia", yet unlike most visitors to cathedrals, many who come to such megachurches spend large parts of their leisure time in these newer mega-spaces. In this sense, Hillsong is another good illustration of a 'full service' church, where life can become all-encompassing for the individual, aided by the church's offering frequent and convenient times of worship at weekends alongside "an ethos of structured diversity" geared towards meeting the interests and needs of different sub-populations (Wade 2016: 666).

Abraham sees Hillsong's global influence as resulting predominantly from its popular brand of worship music, reflecting a clear corporate-style vision of expansion as well as its international reputation as a "hipster megachurch", oriented around global youth fashions in clothes as well as music $(2018: 6-7) \cdot{ }^{6}$ The receptiveness of Hillsong to such trends and its ability to adapt to current

6 Connell (2005: 326) notes that Darlene Zschech, one of the most successful Christian music performers in the world, has been a Hillsong pastor. 
market demands within its Christian subculture permit it to blur boundaries between conventionally evangelical and more charismatic, Pentecostal style of worship and music - a blurring that we see in other megachurches as well. It often appeals to worshippers who do not see Hillsong as their primary denominational affiliation: and so, again, the enclave can expand. Furthermore, the economic dimension of the Hillsong enclave is extended even more by the way it links Christian businesses, for instance through the production of a Christian Business Directory (Connell 2005: 324) in Australia, supported by financial partners that include the National Australia Bank.

While a group such as Hillsong is a product of the 1980 , it is worth reflecting on the experience of older denominations that have themselves become attuned to megachurch attitudes and practices. Joel Osteen's Lakewood Church is currently one of the largest non-denominational congregations in the United States, averaging over 50,000 visitors a week, but it was founded in 1959 by John Osteen, Joel's father, as a more exclusive Baptist Church. The Word of Life is a product of the 1980 s, but it derived much of its impetus from the classical Swedish Pentecostal Movement, which emerged in the country in the early years of the twentieth century. In both of these cases, we see megachurches emerging out of more behaviourally restrictive and conventionally pious forms of Christianity and moving towards much more culturally expansive orientations. ${ }^{7}$ Indeed, Cristina Rocha (2017) argues that the fascination many young middle-class Brazilian migrants to Australia have with Hillsong lies with the group's glamour and inclusivity compared with the more restrictive churches they have experienced back home. It is true that Hillsong does not approve of such behaviours as sex before marriage, but it appears to focus on love of God rather than following specific rules or punishments for minor infractions, and is associated with such famous supporters as the musician Justin Bieber and the Brazilian footballer David Luiz.

One of the most striking examples of this phenomenon of relative 'opening out' to culture and the world comes from Nigeria. The Redeemed Christian Church of God (RCCG) is one of the most active and visible charismatic denominations in the contemporary world, with millions of members and branches in close to 200 countries. It was founded in Christian-dominated south-western Nigeria in $195^{2}$, but remained an almost wilfully obscure,

7 Drawing on the work of George Ritzer (2010), Wade (2016: 666) refers to the broader phenomenon of processes of re-enchantment in late capitalism, including the emergence of "cathedrals of consumption" where magic and wonder are produced through rationalised means, such as large-scale theme parks (see Mathews 2015) - or, perhaps, megachurches. Both Ritzer and Wade draw on Colin Campbell's (1989) famous analysis of the late Calvinist shift from asceticism to forms of consumption and self-construction willed by the divine. 
holiness-oriented group until the early 1980s, when it was taken over by Pastor Enoch Adeboye, a lecturer in mathematics and a powerful and strategic moderniser of his Church (see e.g. Coleman and Maier 2011; Ukah 2008). In 1988, Adeboye helped to catalyse RCCG expansion by sanctioning the development of so-called 'model parishes' designed to attract a more upwardly mobile membership of government, military and academic elites as well as middle and working classes supporters. Speaking English was encouraged rather than purely Yoruba, and the Church adopted a Prosperity message that retained an emphasis on morality yet challenged older, Holiness ideas. Such a shift towards more mainstream attitudes to culture and deportment, including for instance permitting the wearing of jewellery for women, helped create the conditions for a movement that would spread transnationally along with its members as they migrated around the world. In Nigeria itself, the RCCG also created a truly spectacular expansive enclave, a prayer camp located along the Lagos-Ibadan Expressway that now contains two giant auditoria (the larger one three km by three $\mathrm{km}$ in dimensions) alongside extensive housing estates for members, shops, a medical centre, and educational facilities. Like the MFM area that we discussed earlier, the Camp provides a challenge to Lagos city life by presenting its members with an alternative urban lifestyle: but while such a lifestyle is ordered, relatively sober, and gated, it is not afraid to embrace aspects of popular culture, and indeed the Camp now runs its own amusement park that is open to members and non-members alike.

In this section, we have traced the development of varieties of enclaves produced by megachurches located in - but also spreading across - different parts of the world. While restrictive in one sense, drawing a boundary between members and non-members, in practice such enclaves have permitted performances of growth that have suited the cultural expansive styles of broadly evangelical and neo-Pentecostal Christians as they have sought both to retain and to entertain members while extending their cultural reach across all areas of life. In our next section, we move to a related but different form of expansion, that aimed more obviously at non-believers, including efforts to appropriate elements of popular, secular culture in order to appeal beyond the boundaries of the enclave, while keeping within its boundaries of propriety.

\section{Varieties of Encroachment}

Some years ago (2010-2011) I and Katrin Maier, a PhD student, were carrying out fieldwork on the RCCG's activities in London, England. Our first interview was with a young man whom we call Chris, who was happy to tell us about the 
glossy magazine that he had started to edit on behalf of the denomination. ${ }^{8}$ We were sitting in his office at Jesus House, the largest RCCG church in the UK, which was located in an industrial/commercial zone in North London close to Brent Cross, the site of one of the first shopping malls in the country. To the surprise of both Katrin and me, sitting on Chris's desk were not just a Bible but also some distinctly secular-looking publications, such as $G Q$ and Esquire. When he saw us looking at the lurid front covers of the latter, Chris explained that his aspiration was to see his own magazine for sale in high street stores like the famous British stationers W.H. Smith, and so he needed to know how to produce the right format to hit that kind of market. He remarked that he was keen to "learn from the best" publications, even if his aim was not to offer advice on sex or clothes, as they did, but "something better". According to Chris, there were around two million Christian men in the UK, and "they need[ed] to be reached". But his ambitions did not stop there. By referring to W.H. Smith he was indicating his desire to be represented in a store well-known to the entire British population, and one with no obvious religious associations; furthermore, he added that, some day, he hoped to expand his operation into Europe. In a subsequent conversation, I was to encounter Chris's ambitions in another direction as well, when he asked me for advice on how to do a Master's degree in anthropology. He explained that he wanted to deploy the research tools of the social sciences to understand how most effectively to understand - and reach - his target readership. Drawing not just on popular culture, but also on the study of culture, was part of his strategic plan of how to encroach on the world at large.

Chris's example tells us much about wider megachurch attitudes towards expansion. There is certainly an 'enclaving' dimension to his ambition, as he seeks to catch the attention of aspirational and especially younger Christian males, and to do so through offering a cultural product that is of a high professional standard. However, his magazine is clearly meant to encroach upon the secular world in at least two respects: first, through its appropriation of secular formats - products that are potentially of interest to believer and non-believer alike (rather like the songs that Hillsong produces); and second, through his desire for it to compete on the open market, as represented by the high street store. Indeed, Chris's vision has already been achieved by some of the most famous megachurch pastors. If one walks into any larger airport bookstore in Europe or North America and heads for the section selling advice on how to succeed in life, there is a good chance that one will find books by Joel Osteen with titles such as Become a Better You: 7 Keys to Improving Your Life Every Day

8 See also Coleman (2017) for a description of this encounter. 
(2009) and Making Wise Choices - Your Decisions Determine Your Destiny (2005).

In recent years, considerable interest has been paid to the phenomenon of 'spiritual warfare' carried out by many evangelical and Pentecostal believers involving the idea that, through strategic forms of prayer, Christians can 'take back' secular territory and associated culture from demonic powers, and place them under the control of divine order. While such warfare constitutes a striking and often spectacular example of how the world at large may be perceived with mistrust, it is important to bear in mind that other means of approaching the secular world are available, such as the encroachments through popular culture described in this chapter. Once again, a balance must be struck. Wade (2016: 669) talks of Hillsong erecting a "partition of insularism" through invocations of "the enemy" and yet also reaching out into the world of the unsaved (and spiritually vulnerable) at the same time.

A recent and increasingly popular example of evangelical missionising that manages simultaneously to enclave and to encroach is provided by the phenomenon of Hell Houses, which have been observed by one of us (Chattoo) in congregations in the American South. Often produced to compete with Halloween, these are theatrical events that enact sinful situations in front of believers and non-believers, depicting the consequences of continuing to live a sinful life. The staging of realistic scenarios is often followed by an earnest attempt to convert unsaved audience members. Both entertaining and potentially frightening, Hell Houses come close to the secular horror genres from which they draw some influence, and yet they flip the spiritual register of the theatrical event towards evangelical intentions and values.

The negotiation of the balance between encroaching and enclaving emerged in another area of Chattoo's fieldwork, involving her observation of a longstanding internal debate about the use of 'secular' music in relation to an American Assemblies of God competition known as Fine Arts. The use of 'secular' popular music has become an important narrative tool in a Fine Arts performance category known as 'Human Videos,' where a live movement piece juxtaposes scenes from a fallen world (set to 'secular' music) before switching to worship music that backgrounds performances of Jesus' redemptive power. However, with recent performances having introduced popular music choices that were perceived by some members as going 'too far,' debates about what it means for youth to interact with this type of popular music reignited discussions in the community about the potential harm of including such media in church projects of youth education and ministry. New rules were set in place to ensure that teams were choosing their music thoughtfully, while calls to ban popular music outright were rejected. A document was published to justify the 
contentious decision, explaining that in addition to honing their performance skills for a future of confident and effective ministry, Fine Arts should be a place where young members of the church can engage in critical thinking about how to negotiate the tensions and complexities of bringing Christ to a fallen world.

This latter example allows us to make a productive ethnographic contribution to longstanding academic debates about processes of negotiating the use of popular culture mediums in megachurch spaces (Sargeant 2000; Twitchell 2007; Wilford 2012). Certainly, an important aspect within the scholarship addresses current theological debates regarding how one might interact with the world enough to save it without becoming of it in the process. The example also helps us contribute to the project of complicating the "religious market principle" that other scholars have already taken up (Wilford 2012), given that Fine Arts is its own microcosm of sorts. If one wishes to compete, one must be a member of an Assemblies of God church and must follow the rules as set by the centralised body of rule-makers. Thus, while certain aspects of the creative process can be "shopped" for (Twitchell 2007) by attending different churches and competing in different districts, ${ }^{9}$ ultimately, students and parents want to compete on the national leve ${ }^{10}$ and have a vested interest in remaining members and actively debating the parameters of youth outreach. Though the district level of competitions enacts similar situations to the forming of small groups in a process akin to what Wilford terms "how to make a big church small," there are always ways that the church becomes "big" again (2012, 9093). Considering the performance-based ministry microcosm of Fine Arts as one of the many spaces where questions of boundaries of belonging are drawn (and redrawn) adds to conversations around the "flexibility" of such megachurches "in how they express their theology" (Sargeant 2000, 166).

As a means of encroachment on the world, the deployment of popular culture may have the particular advantage for some evangelical populations of carving out a realm of influence in societies where direct political engagement is difficult. Thus Terence Chong (2015) provides an account of the growing appeal of megachurches to emergent middle-class Singaporeans. In Chong's analysis, such churches have proved to be effective in their deployment of marketing strategies and the promotion of a consumerist and self-help ethos, expressed through such media as rock-concert-like worship and televised

9 Discussions in social spaces abound regarding which churches and indeed, even districts are more or less lenient on issues such as the use of 'secular' popular music.

10 The national level is where students can bank money for college scholarships for use at any Assemblies of God institution, which is one of the largest motivating factors for Chattoo's interlocutors' years of dedicated financial and emotional investment. 
sermons, alongside the visual aesthetics of the shopping mall. So far, such actions - alongside a good deal of ministering to the disadvantaged - have been maintained without creating conflict with the Singaporean state, and indeed the churches have catered to welfare needs and materialist desires alike without critiquing the operations of capitalist governance.

Other contexts of operation provide very different opportunities for encroachment. In Brazil, for instance, the Universal Church of the Kingdom of God, founded in 1977 in Rio de Janeiro, now owns one of the largest television networks in the country, which supports the aims of some of its members to take political office. In this sense, the Church is seeking to link together not only different aspects of members' lives, but also the economic, civic, religious, and political realms of society at large: popular culture is thus seen as a contributor to a form of theocracy. The Universal Church is often deeply controversial (even 'unpopular'), but benefits from seeking influence within a national context where religious discourse is widespread. In certain respects a similar situation is described by Birgit Meyer (2004: 92) in her discussion of how, over the last few decades, popular culture and Christianity have expanded in tandem in Ghana as the country has moved towards democracy and a liberalisation of the media. Just as the Ghanaian video-film industry has expanded, so it has echoed the views of widespread Pentecostalist-charismatic churches, contributing to what Meyer terms a pentecostally infused, or 'pentecostalite', public culture. In using this term, she refers more broadly to the deployment of expressive forms that allow such religion to operate in spheres of entertainment - music, theatre, radio, radio programs, as well as videofilms - that constitute a genuinely 'popular' culture. Furthermore, we see how supposedly secular activitities can borrow from the religious world, and not simply the other way round.

\section{5}

\section{Concluding Remarks}

Over the past century and more, evangelical Christians (including Pentecostalists and charismatics) have often been accused either of opposing and demonising the world at large, or of simply capitulating to its temptations in the search for fame, fortune, and power. We hope in this chapter to have used an examination of megachurch deployments of popular culture to complicate this binary view of such Christians, and to indicate some of the subtleties of engagement and motivation among believers who constitute their very identity through inhabiting a space of agency that lies on the border of, and frequently crosses between, redeemed and unredeemed arenas of action. The enclave offers a space of relative spiritual and social security, but it is not enough: 
believers must also perceive themselves - or their surrogates in the varied forms of preachers, records, magazines, television programmes, websites, and so on - as reaching out into a world that may be more likely to accept their presence if they adopt cultural forms that do not look too alien to the average city- or suburb-dweller.

While revivalist churches have always had to cultivate something of a populist dimension, in recent decades megachurches have taken their expansive performances into some newer territories, engaging in a double-pronged strategy of retaining members and attempting to attract new ones by accepting the value of popular culture as a means of communication, but one whose morality needs to be monitored. This relative shift from the 'pious' to 'the popular' should not be seen in simple terms as a surrender to secularity. Rather, it provides a means to engage in the sometimes difficult discipline of having to expand into new economic, cultural, social, and even national territories as a means of acknowledging and responding to the constant demands of performing the 'mega'.

\section{References}

Abraham, I. 2018. "Sincere Performance in Pentecostal Megachurch Music." Religions. 9, 192; DOI:10.3390/relgo6o192.

Beckering, D. 2011. "From 'Televangelist' to 'Intervangelist': The Emergence of the Streaming Video Preacher." Journal of Religion and Popular Culture. 23:2, 101-117.

Brenneman, R. and B. Miller. 2016. "When Bricks Matter: Four Arguments for the Sociological Study of Religious Buildings." Sociology of Religion. 77:1, 82-101.

Brown, C. 2012. "Selling Faith: Marketing Christian Popular Culture to Christian and Non-Christian Audiences." The Journal of Religion and Popular Culture. 24:1, 113-129. Campbell, C. (1989) The Romantic Ethic and the Spirit of Modern Consumerism. Oxford: Blackwell.

Carney, C. 2012. "Lakewood Church and the Roots of the Megachurch Movement in the South." Southern Quarterly. 50:1, 1-78.

Chong, T. 2015. "Megachurches in Singapore: The Faith of an Emergent Middle Class." Pacific Affairs. 88:2, 215-235.

Coleman, S. 2000. The Globalisation of Charismatic Christianity: Spreading the Gospel of Prosperity. Cambridge: Cambridge University Press.

Coleman, S. 2017. "Morality, Markets and The Gospel of Prosperity." In F. Osella and D. Rudnyckyj eds Religion and the Morality of Markets. Cambridge: Cambridge University Press, $5^{0}-71$. 
Coleman, S. and K. Maier. 2011. "Who Will Tend the Vine?: Pentecostalism, Parenting and the Role of the State in London-Lagos." Journal of Religion in Europe 4(3): $45^{0}-470$.

Coleman, S. and M. Bowman. 2018. Religion in Cathedrals: Pilgrimage, Heritage, Adjacency, and the Politics of Replication in Northern Europe, Religion, DOI: 10.1080/0048721X.2018.1515341

Connell, J. 2005. "Hillsong: A Megachurch in the Sydney Suburbs." Australian Geographer. 36:3, 315-332.

Douglas, M. 1993. In the Wilderness: The Doctrine of Defilement in the Book of Numbers. Journal for the Study of the Old Testament, Supplement Series 158.

Eagle, D. 2015. "Historicizing the Megachurch." Journal of Social History. 48:3, 589-6o4. Ebel, J. 20og. "Jesus Freak and the Junkyard Prophet: The School Assembly as Evangelical Revival." Journal of the American Academy of Religion. 77:1, 16-54.

Feldman, J. 2002. "Marking the Boundaries of the Enclave: Defining the Israeli Collective through the Poland 'Experience'." Israel Studies. 7: 2, 84-114.

Gardner, C. 2017. "Popular Culture and the Evangelical Imagination." Rhetoric and Public Affairs. 20:1, 161-175.

Goh, R. 2008. "Hillsong and 'Megachurch' Practice: Semiotics, Spatial Logic and the Embodiment of Contemporary Evangelical Protestantism." Material Religion. 4:3, 284-305.

Johnson, B. 2011. "Back to the Heart of Worship: Praise and Worship Music in a Los Angeles African-American Megachurch." Black Music Research Journal. 31:1, 105-129.

Kilde, J. 1999. "Architecture and Urban Revivalism in Nineteenth-Century America." In P. Williams ed. Perspectives on American Religion and Culture. New York: Blackwell, 174-186.

Lindenbaum, J. 2012. "The Pastoral Role of Contemporary Christian Music: The Spiritualization of Everyday Life in a Suburban Evangelical Megachurch." Social and Cultural Geography. 13:1, 69-88.

McDannell, C. 1995. Material Christianity. New Haven: Yale University Press.

Maddox, M. 2012. "In the Goofy Parking Lot': Growth Churches as a Novel Religious Form for Late Capitalism." Social Compass. 59:2, 146-158.

Mathews, J. 2015. “Theme Park Bibles: Trinity Broadcasting Network's Holy Land Experience and the Evangelical Use of the Documentary Past." Journal of Religion and Popular Culture. 27:2, 89-104.

Meyer, B. 2004. "Praise the Lord": Popular cinema and Pentecostalite style in Ghana's New Public Sphere.' American Ethnologist 31:1, 92-110.

Oosterbaan, M. 2015. "Mediating Culture: Charisma, Fame, and Sincerity in Rio de Janeiro, Brazil." In S. Coleman and R. Hackett eds, The Anthropology of Global Pentecostalism and Evangelicalism. New York: New York University Press, 161-176. 
Osteen, Joel. 2005. Making Wise Choices - Your Decisions Determine Your Destiny. Houston: Joel Osteen Ministries.

Osteen, Joel. 2009. Become a Better You: 7 Keys to Improving Your Life Every Day. New York: Howard Books.

Ritzer, G. (2010) Enchanting a Disenchanted World. London: Sage.

Robbins, J. 2004. "The Globalization of Pentecostal and Charismatic Christianity." Annual Review of Anthropology. 33, 117-143.

Rocha, C. 2017. “The Come to Brazil Effect:" Young Brazilians' Fascination with Hillsong.' In T. Riches and R. Wagner eds, The Hillsong Movement Examined. Basingstoke: Palgrave Macmillan, 125-141.

Sargeant, Kimon Howland. 2000. Seeker Churches: Promoting Traditional Religion in a Nontraditional Way. New Brunswick, N.J: Rutgers University Press.

Twitchell, James B. 2007. Shopping for God: How Christianity Went from in Your Heart to in Your Face. New York: Simon \& Schuster.

Ukah, Asonzeh. 2008. A New Paradigm of Pentecostal Power. A Study of the Redeemed Christian Church of God in Nigeria. Trenton/Asmara: Africa World Press.

Wade, M. 2016. "Seeker-friendly: The Hillsong Megachurch as an Enchanting Total Institution." Journal of Sociology. 52:4, 661-676.

Walton, J. 2011. "For Where Two or Three (Thousand) Are Gathered in My Name! A Cultural History and Ethical Analysis of African American Megachurches." Journal of African American Studies. 15:2, 133-154.

Wilford, Justin G. 2012. Sacred Subdivisions: The Postsuburban Transformation of American Evangelicalism. New York: New York University Press. 